\title{
Alterations in innate antibacterial response after immunomodulatory nutrition
}

\author{
Zmiany wrodzonej odpowiedzi przeciwbakteryjnej po żywieniu \\ immunomodulacyjnym
}

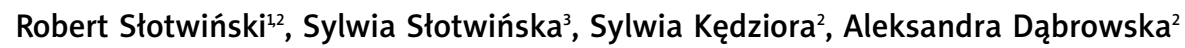 \\ 1Department of Surgical Research and Transplantology, Polish Academy of Sciences Medical Research Center, Warsaw, Poland \\ 2Department of Immunology and Nutrition, Medical University of Warsaw, Poland \\ ${ }^{3}$ Department of Conservative Dentistry, Medical University of Warsaw, Poland
}

Prz Gastroenterol 2012; 7 (3): 115-124 DOI: $10.5114 / p g .2012 .29876$

Key words: innate immunity, immunonutrition, Toll-like receptors.

Słowa kluczowe: wrodzona odporność, żywienie immunomodulacyjne, receptory Toll-podobne.

\begin{abstract}
Address for correspondence: Prof. Robert Stotwiński MD, PhD, Department of Immunology and Nutrition, Medical University of Warsaw, 3 Pawińskiego, 02-106 Warsaw, Poland, phone: +48 22 5720247, fax: +48 22 5720246, e-mail: robert.slotwinski@wum.edu.pl, robert_slotwinski@yahoo.com
\end{abstract}

\begin{abstract}
Septic infections in malnourished surgical patients show the highest morbidity and mortality rate. The attempt to correct postoperative immune and nutritional disorders by introducing immune-enhancing nutrition (immunonutrition) is a promising way of improving outcome, but as yet little is known about the mechanisms of correcting an extensive postoperative inflammatory response (systemic inflammatory response syndrome [SIRS]) to a massive infection using this type of nutrition. A significant role in the innate antibacterial and inflammatory response is played by Toll-like receptors (TLRs) that recognize pathogen-associated molecular patterns (PAMPs). The regulatory impact of immunonutrition on TLR expression in surgical septic patients seems to be a new research direction. In this paper special emphasis was put on clinical trials and the research results for the TLR-dependent immune response and anti-bacterial/anti-inflammatory response applying immunomodulatory nutrition with increased concentrations of glutamine and unsaturated fatty acids.
\end{abstract}

\section{Introduction}

Despite advances in treatment methods, there is still no therapy available to efficiently reduce the excessive inflammatory response, which can increase the risk of multiple organ failure in patients treated in intensive care units (ICUs). One of the ways to discover new, more efficient treatment methods involves regulating the

\section{Streszczenie}

Zakażenia septyczne w grupie niedożywionych pacjentów chirurgicznych obarczone są najwyższym wskaźnikiem chorobowości i śmiertelności. Korekcja pooperacyjnych zaburzeń odporności i niedożywienia poprzez żywienie immunomodulujące jest obiecującą metodą uzyskania lepszych wyników leczenia, ale nadal niewiele wiadomo o mechanizmach regulacji zwiększonej pooperacyjnej odpowiedzi zapalnej (systemic inflammatory response syndrome - SIRS) na masywne zakażenie za pomocą tego typu terapii. Istotne znaczenie w regulacji wrodzonej odpowiedzi przeciwbakteryjnej i przeciwzapalnej mają receptory TLRs (Toll-like receptors), rozpoznające związane z patogenami wzory molekularne (pathogen-associated molecular patterns - PAMPs). Ocena regulacyjnego wpływu żywienia immunomodulacyjnego na ekspresję receptorów TLR u septycznych pacjentów chirurgicznych jest nowym kierunkiem badań naukowych. W przedstawionej pracy szczególną uwagę zwrócono na wyniki badań klinicznych i eksperymentalnych dotyczące regulacji zależnej od TLRs odpowiedzi przeciwbakteryjnej/przeciwzapalnej za pomocą żywienia immunomodulacyjnego, zawierającego zwiększone stężenia glutaminy i nienasyconych kwasów tłuszczowych.

mechanisms of inflammatory response to a massive infection by using immune-enhancing nutrition (immunonutrition). The results of a meta-analysis of randomized studies have shown that in a group of seriously ill patients (systemic inflammatory response syndrome [SIRS], acute respiratory distress syndrome [ARDS]) immunomodulatory treatment with glutamine and fatty acids improves outcomes, which has not been con- 
firmed after the enteral administration of arginine [1]. Another meta-analysis covering the perioperative results of immunonutrition aimed at enhancing immunity in patients operated on for tumors of the digestive tract has shown a decrease in the number of postoperative complications, reducing the length of hospital stay and improving selected immune parameters such as an increase in the total number of lymphocytes, subpopulation of CD4 lymphocytes, and concentration of IgG, and a decrease in the concentration of IL-6 [2]. Compared with the standard immunonutrition, the enteral administration of glutamine, arginine and/or fatty acids ( $n-3$ PUFAs: $n-3$ polyunsaturated fatty acids) in patients with acute pancreatitis shows no significant impact on decrease in the number of complications, the length of hospital stay or mortality rate [3]. Considering another review of study results the advantageous impact of enteral and parenteral administration of immunonutrition in patients with acute pancreatitis can be enhanced by administering inflammatory and immune response modulators [4]. In the group of patients after extensive surgical trauma, adding glutamine has always resulted in a decrease of post-surgical complications, reduction in the length of hospital stay and even a reduction of the mortality rate in seriously ill patients [5]. Multi-center studies have shown that the administration of high doses of glutamine associated with antioxidants in seriously ill patients hospitalized in ICUs results in a significant increase in morbidity and mortality [6]. The majority of studies that have been carried out to date show that $n-3$ PUFAs have a significant regulative impact on the immune response and outcomes in patients after surgery with serious infections including ARDS $[7,8]$. The enteral administration of unsaturated fatty acids in septic patients is still controversial due to the lack of prospective randomized studies. We still know very little about the mechanism of action of $n-3$ PUFAs which is among other things supposed to reduce the negative impact of n-6 PUFAs on the immune system (inflammatory response reduction). Considering the summary of the recent meta-analysis covering the outcomes of 3013 patients treated mainly in ICUs, immunomodulating nutrition containing fish oils significantly improved the outcomes for those patients [9]. The authors of the meta-analysis emphasize that arginine-enriched diets with no glutamine or fish oil added do not improve outcomes as compared with standard immunonutrition.

The promising results of experimental studies on treating severe infections with lipopolysaccharide (LPS) inhibitors, tumor necrosis factor $\alpha$ (TNF- $\alpha$ ), interleukin-1 (IL-1), platelet activating factor (PAF), nitric oxide (NO), arachidonic acid metabolites, complement component inhibitors or free radicals did not considerably reduce the highest mortality rate in septic patients [10]. Other interesting strategies for the treatment of sepsis based on attempts to block LPS-binding receptors and on blocking signaling pathway proteins for the antibacterial response, e.g. blockade of Toll-like receptor (TLR)4, caspases, FasL-Fas or NF-kB activity, and blocking the high mobility group box 1 (HMGB1) pathway as well as on attempting to regulate neutrophil and lymphocyte apoptosis (e.g. by overexpression of anti-apoptotic proteins such as $\mathrm{Bcl}-2$ ) are still under experimental research [10-14]. It is well known that neutrophils and monocytes/macrophages taking part in the innate immune response to trauma and infection play a significant role in the elimination of microorganisms as well as in local and systemic inflammatory response regulation (SIRS: systemic inflammatory response syndrome) that increases the risk of multiple organ failure [15]. It is suggested that the modulation of TLR expression found in the cells of intestinal mucous membrane, neutrophils, monocytes and dendritic cells (DCs) binding bacterial antigens and the modulation of expression of signaling pathway proteins of those cells by early administration of appropriate immunonutrition can help efficiently eliminate microorganisms and reduce the inflammatory response (production of cytokines, chemokines). These issues make us ask the basic and still open question: Can the re-programming of signal transduction pathways in intestinal mucosa and innate immunity cells of septic patients after administering immunonutrition contribute to attenuation of the local and systemic hyperinflammatory response in massive bacterial load?

\section{TLR signaling and immunonutrition TLR-dependent anti-bacterial response}

TLRs recognize a few highly conservative structures existing in prevailing microorganisms. Thirteen TLRs have been identified (including 11 in humans). Additionally, it was indicated that they showed mainly affinity to bacteria (TLR1, 2, 4, 5, 6). Some of them (TLR3, 7, 8, 9) also show some affinity to viral RNA and DNA. The prevailing TLRs show expression on the surface of cells (TLR1, 2, 4, 5, 6), but some of them can also be active inside cells and occur on the surface of endosomes (TLR3, 7, 8, 9) [16, 17]. However, it is still unknown how ligands for those receptors (e.g. exogenous ligands: LPS, peptidoglycan, bacterial DNA) penetrate into the cells. The endogenous ligands for TLRs include mainly some heat shock proteins (HSP60, HSP70) released from injured cells.

The production of the LPS receptor complex (CD14, TLR4, MD-2) induces dimerization of TLR4 and initiates a signaling cascade which results in activation of phos- 


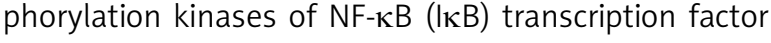
inhibitor. This process induces transcription of genes whose products take part in the inflammatory response (e.g. cytokines TNF- $\alpha$, IL-1, IL-6, IL-12). Apart from the role of extracellular TLRs in the signaling cascade of the antibacterial response, there are also such "participants" as a cytoplasmic part referred to as the TIR domain (Toll-IL-1 receptor), adaptor protein MyD88 (myeloid differentiation factor 88), TIRAP (TIR-domaincontaining adaptor protein) and TRAM (TRIF-related adaptor molecule), the protein TRIF (Toll/IL-1-receptor domain-containing adaptor inducing interferon), TRAF6 (TNF- $\alpha$ receptor-associated factor 6 ), kinases (IRAK1, IRAK4 - IL-1 receptor-associated kinases; TAK - transforming growth factor $\beta$ (TGF- $\beta$ )-activated kinases) and a kinase complex (IKK- inhibitory $\kappa B$ kinase complex) [18-20]. The MyD88, TRAF6, TRIF and TRAM proteins are key proteins of signaling pathways initiated by TLRs, which can be of significant importance in treating sepsis [21, 22]. This process results in the activation of $\mathrm{NF}-\kappa \mathrm{B}$ and cytokine promoter genes. The production of inflammatory cytokines begins as soon as $60 \mathrm{~min}$ after the activation of macrophages by TLR4-binding LPS. In the case of MyD88-dependent transduction of the signal from TLR4 and TLR2, the TRAF6 protein plays a significant role, while in the case of the MyD88-independent pathway the main participants include TRAM and TRIF proteins (Figure 1). Attempts to block the signaling cascade in patients with severe infections attract the interest of many scientists. Especially interesting may be the use of negative regulation of signaling pathways associated with TLRs (e.g. RP 105/CD180 protein: TLR homolog, single immunoglobulin IL-1-receptor-related protein, signaling TIR family ligand, Toll-interacting protein; or Smad6), whose mechanism consists in suppressing the location of the bond between the ligand (LPS) and the receptor, proteolysis of TLR, blocking intracellular receptors binding antibacterial antigens, blocking the activity of kinases (suppression of phosphorylation process) and suppressing the activation of $\mathrm{NF}-\kappa \mathrm{B}$ [23-28]. Numerous experimental studies indicate the possibility of conduction of signals from TLRs to the inside of cells after connecting with LPS, which may prevent the activation of NF- $\mathrm{KB}$. Mice deprived of signaling pathway proteins associated with TLR4 (TIRAP, MyD88, TRIF) do not respond to LPS and are resistant to septic shock [29-32]. On the other hand, mice deprived of TLR2 and the MyD88 adaptor protein are more susceptible to Staphylococcus aureus infections [33]. This indicates a protective action of some TLRs and adaptor proteins. In mice deprived of MyD88 protein, the systemic inflammatory response to LPS was significantly reduced but still present, which suggests coop- eration of other routes of signal conduction in the antibacterial response [34]. The above-mentioned fact at least partly shows that the effects of treatment are insufficient due to the blockage of signal conduction routes.

TLRs expressed in mucosal cells and in the cells that take part in the innate response to infections play a significant role in antibacterial response modulation in patients with severe infections. The TLRs recognize the structural components of microorganisms and occur both inside and outside cells (intra- and extracellular TLRs). Some studies show that trauma reduces, whereas a severe infection increases the expression of TLRs recognizing bacterial antigens (e.g. LPS, peptidoglycan) [35-38]. Compared with healthy people, the expression of TLR4 in the monocytes of trauma patients was reduced [36]. Therefore, it is tempting to postulate that increased expression of TLRs would have a beneficial effect in trauma patients. Polymorphism of TLRs was one of the factors that increased the susceptibility to infections caused by particular bacteria, but in patients with mixed severe infections did not show any significant effect on their course and outcome [39]. In some experimental studies a lack of TLRs increased the susceptibility to infections in mice [40] and caused disorders in inflammatory mediator secretion as well as disorders in phagocytosis and antigen presentation [41-43]. Intraperitoneal administration of living Escherichia coli bacteria or LPS TLR4 had a significant impact on the phagocytic activity of peritoneal macrophages. Lack of TLR2 and TLR4 in macrophages caused disorders in bacterial phagocytosis (E. coli, Staphylococcus aureus). The experimental findings suggest that TLR4 plays a key role in regulating the expression of inflammatory cytokines in the lung during endotoxic shock [44]. Six hours of LPS administration induced a significant increase in pulmonary TNF- $\alpha$, IL- $1 \beta$ and IL- 6 mRNA in control (TLR4+) mice compared to TLR4-deficient mice [44]. Recent studies showed that apoptotic macrophages can have a protective action in septic shock caused by LPS administration in mice [45]. This study for the first time demonstrated that the administration of apoptotic cells could protect mice against LPS-induced death, even when the apoptotic cells were administered $24 \mathrm{~h}$ after the LPS challenge. The beneficial effects of administration of apoptotic cells included the reduced circulation of pro-inflammatory cytokines (TNF- $\alpha$ ), enhancement of IL-10 expression by LPS-activated macrophages, suppression of neutrophil infiltration in target organs, and decreased serum LPS levels. The apoptotic cells were an LPS carrier, which facilitated its phagocytosis and LPS elimination. This study showed that not TLR4, but CD14 is one of the receptors for LPS-coated apoptotic cell 


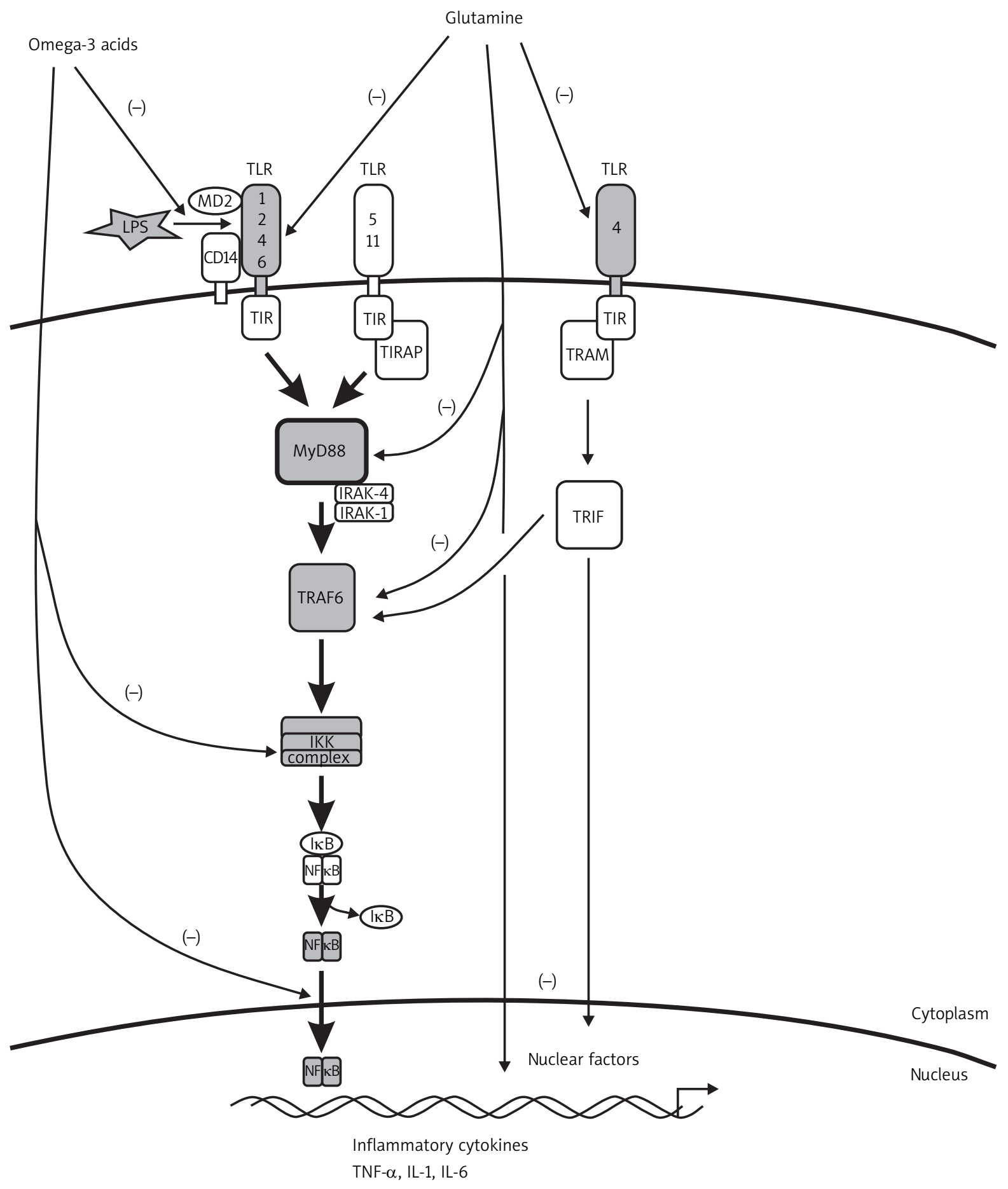

TLR - Toll-like receptor, TIR - Toll-IL-1 receptor, TIRAP - TIR-domain-containing adapter protein, TRAM - TRIF-related adapter molecule, TRIF - Toll/IL-1-receptor domain-containing adapter inducing IFN, MyD88 - myeloid differentiation factor 88, TRAF6 - TNF- $\alpha$ receptor-associated

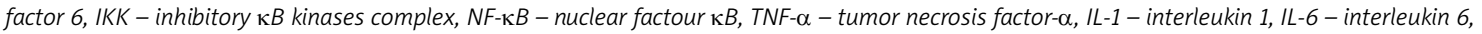
LPS - lipopolysaccharide

Fig. 1. Schematic diagram of TLR4, MyD88 and TRAF6 down-regulation in rat intestinal mucosa following glutamine administration and LPS-induced endotoxemia. N-3 PUFA inhibition of TLR signaling pathway at the extracellular (DHA interference with TLR4 receptor) and intracellular level: inhibition of the phosphorylation and degradation of $\mathrm{I} B_{\mathrm{B}}$, inhibition of NF- $\mathrm{KB}$ activation and inflammatory cytokine production in LPS-stimulated human leukocytes and macrophages

Ryc. 1. Schemat hamowania kaskady sygnałowej TLR4, MyD88 i TRAF6 w błonie śluzowej jelita po podaniu glutaminy u szczurów z zakażeniem wywołanym przez LPS. Zależne od kwasu tłuszczowego (n-3 PUFA) zewnątrzkomórkowe hamowanie kaskady sygnałowej TLR (przez wpływ kwasu DHA na receptor TLR4) i wewnątrzkomórkowe (przez hamowanie fosforylacji i degradacji czynnika I B), hamowanie aktywacji czynnika NF- $\kappa B$ i produkcji cytokin zapalnych w ludzkich leukocytach i makrofagach po stymulacji LPS 
uptake. The experimental study suggests that the LPSinduced decrease of neutrophil apoptosis takes place mainly through TLR2, not through TLR4, but apoptosisassociated factors such as Bcl-XL or Bak do not play a major role in this process [46]. The regulation of this signaling pathway is crucial for decreased neutrophil apoptosis during sepsis, which may amplify and prolong any systemic inflammatory response.

After partially successful attempts to block LPSbinding receptors in septic patients and blocking the signaling pathway proteins associated with the antibacterial immune response (e.g. suppression of HMGB1), the attempts to modulate the response by immunonutrition seem to be a new and promising direction of studies. To date, several randomized clinical trials have evaluated the efficacy of arginine, glutamine, $\omega-3$ fatty acids, nucleotides and trace elements with antioxidant properties in critically ill patients with trauma and/or infections, but the basic molecular mechanisms that can attenuate the overwhelming inflammatory response in sepsis are still unclear. In malnourished surgical patients with infections, the direct factor that intensifies the failure of local "first line" antibacterial defense may be disorders of PAMPs (e.g. LPS, peptidoglycan, teichoic acids, bacterial DNA) recognition by innate immunity cells. The increased activation of receptors taking part in PAMP recognition can lead to development of severe infections. The hypothesis that one of the main reasons for false recognition of bacterial antigens by immune system cells (mainly by phagocytic cells) is malnutrition is highly probable. The deficiency of immunoactive nourishing substances (e.g. glutamine, fatty acids or trace elements such as selenium and zinc) can intensify the disorders of expression of bacterial antigen binding extracellular receptors and intracellular proteins/receptors. The excessive accumulation of bacterial wall fragments and the microorganisms proliferating in tissues intensify the inflammatory response and increase the release of cytokines into the blood.

\section{Glutamine}

Glutamine, the most abundant amino acid in the human body, performs multiple roles in the intestine and may even serve as a signaling molecule [47]. Glutamine is an important energy source for lymphatic tissue and glutamine-enriched enteral nutrition has been found to reduce the incidence of sepsis in trauma patients, due to maintaining the integrity of intestinal mucosa $[5,48,49]$. Animal studies indicate that glutamine-supplemented total parenteral nutrition decreases bacterial translocation [50]. The experimental studies showed that adding glutamine to a culture of neutrophils taken from patients after surgical trauma increases their antibacterial activity [51]. Low plasma glutamine concentrations $(<0.42 \mathrm{mM})$ at admission to ICUs were associated with higher severity of illness and higher mortality rates [52]. Glutamine deprivation can upregulate an important pro-inflammatory mediator (LPS-induced IL-8 production) via decrease of the inhibitor $\kappa \mathrm{B}$ in both the immature and mature human intestine, showing the greatest response with the immature intestine [53]. The production of IL- 8 by LPSstimulated human blood monocytes in vitro was increased along with increasing glutamine concentration [54]. The results of recent studies show the regulative impact of glutamine on the inflammatory response in severe infections and indicate that it is necessary to administer high doses (e.g. in parenteral administration $0.35 \mathrm{~g} / \mathrm{kg} \times$ day) to obtain a better therapeutic effect $[49,55,56]$.

Some of the most recent experimental studies show that the enteral administration of glutamine reduces the increased expression of TLR4, signal adaptor protein MyD88 and TRAF6 mRNA in intestinal mucosa as a response to LPS-induced endotoxemia in rats (Figure 1) [14]. In addition, the above-mentioned studies found a decreased level of injury to the mucous membrane of the small intestine. It is well known that TLR4 mRNA is present in mouse and human intestinal epithelial cell TLR4 lines [57] and the upregulation of expression of TLR4 and MyD88 after LPS leading to the induction of inflammatory cytokines such as TNF- $\alpha$, IL-1 and IL- 6 can explain the development of intestinal mucosal injury.

Another study [58] suggested that downregulation of TRL4 expression may be a mechanism used by intestinal epithelial cells to protect against dysregulated immune signaling in response to Gram-negative bacteria. In the case of critical care patients a recent study showed that parenteral nutrition supplemented with glutamine does not increase the expression of TLR2 or TLR4 in peripheral blood monocytes [59]. In trauma patients in the ICU, total parenteral nutrition (TPN) supplemented with glutamine does not improve the expression or the functionality of TLRs in peripheral blood monocytes [60]. The mechanisms whereby glutamine prevents the occurrence of infection are still unclear, but it is well known that glutamine decreases the production of pro-inflammatory cytokines [61, 62] and improves the bactericidal function of neutrophils in the case of surgical or burn patients [63]. In cultured colonic biopsies from patients with active Crohn's disease, glutamine was found to decrease TNF- $\alpha$ and the main pro-inflammatory cytokines released by NF-אB [64]. The impact of glutamine on TLR4 may suggest modulation of expression of other signaling proteins through omitting the main pathway with the MyD88 protein (e.g. by 
regulating the expression of TRIF protein). Our last study suggested that in malnourished pancreatic cancer patients glutamine may be a modulator for the innate immune system (unpublished data). In patients with pancreatic cancer a statistically significant increase of TLR4 ( $p=0.0001)$ and NOD1 $(p=0.004)$ gene expression (measured by real-time RT-PCR) was observed in peripheral blood leukocytes as compared with the control group of healthy volunteers. Treatment with glutamine (pre-operative enteral administration for 5 days, $20 \mathrm{~g}$ of glutamine per day) was associated with significantly decreased TLR4 gene expression (Figure 2). We suggested that one of the mechanisms by which pre-operative enteral immunonutrition with glutamine decreases the incidence of post-operative septic complications in malnourished pancreatic cancer patients is probably associated with down-regulation of TLR4 expression.

\section{Omega-3 fatty acids}

The anti-inflammatory action of unsaturated fatty acids (including mainly n-3 PUFAs) and their use in treating early sepsis (in the first phase of sepsis syndrome) still seem to be very interesting. In traumatized and surgical patients an enteral diet containing $n-3$ fatty acids significantly reduced infectious complications and septic events [65-67]. Enhanced survival and reduced lung failure after enteral or parenteral administration of $n-3$ PUFAs was observed in experimental models of sepsis [68-70]. Interestingly, by incorporation into various

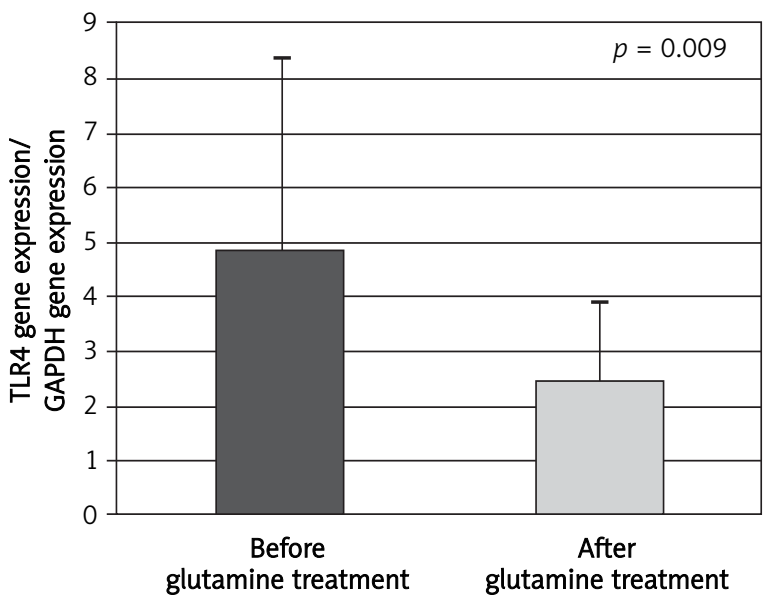

Fig. 2. Significantly decreased TLR4 gene expression in peripheral blood leukocytes of malnourished patients with pancreatic cancer after preoperative enteral glutamine administration

Ryc. 2. Istotne obniżenie ekspresji genu TLR4 $w$ leukocytach krwi obwodowej u niedożywionych osób z rakiem trzustki po przedoperacyjnym dojelitowym podaniu glutaminy membrane (phospho)-lipid pools, n-3 PUFAs may affect lipid-signaling events in different cell types [71, 72]. The $\omega-3$ fatty acids also have an ability to selectively suppress the signaling cascade associated with the innate antibacterial response (mainly leukocytes and macrophages), independently at successive stages: 1) endotoxin interaction with TRL4, 2) activation of inhibitor phosphorylation kinases of the NF- $\kappa B(\mid \kappa B)$ transcription factor and 3) translocation to the nucleus and connecting NF- $\mathrm{KB}$ to an appropriate DNA sequence (suppressing the transcription of inflammatory response mediator genes; Figure 1) [73-80]. The concept of free n-3 PUFAs as a TLR4 antagonist has not been demonstrated in vivo. Docosahexaenoic acid (DHA) can block the conduction of signals at the TRL4 level [11], which indicates the key role of the receptor in regulating the response to increased concentrations of fatty acids in peripheral blood during sepsis. The interaction of those fatty acids with TRL4 intensifies the inflammatory response, and increases insulin resistance and tissue injury [81]. We can prevent it by administering appropriate nutrition mixtures. It has been demonstrated that the enteral administration of a diet enriched in unsaturated fatty acids (eicosapentaenoic acid - EPA) and glutamine in septic patients treated in ICUs reduced the inflammatory response and mortality rate caused by acute lung injury (ALI) $[82,83]$. The enteral administration of $n-3$ acids in septic patients modulated the functions of neutrophils, and changed the disadvantageous proportion of $n-6$ acids to $n-3$ in the direction of higher concentration of n-3 acids, which was associated with lower concentrations of pro-inflammatory cytokines $[84,85]$. In mice, EPA- and DHA-enriched diets modulate the balance between pro- and anti-inflammatory cytokines, alter the early response of the host to Pseudomonas aeruginosa infection, and affect the early outcome of infection [86]. Recent findings for the first time indicate that LPS administration causes the downregulation of TLR4 at the mRNA and protein level in pig adipose tissue and that dietary n-3 PUFA blocks this response [87]. In spleens from mice fed a fish oil diet, an increased proportion of macrophages secreting TNF- $\alpha$ and IL-10 and expressing the LPS receptor complex molecules CD14 and TLR4/MD-2 was observed [88]. The expression of TLR2 and TLR4 on peritoneal macrophages and DCs from mice treated with a combined diet (soybean isoflavones and green tea) was significantly decreased [89].

The investigation of Lee and Hwang revealed that saturated and unsaturated fatty acids circulating in the blood can modulate TLR4 signaling by acting as agonists or antagonists [90] For instance, lauric acid (C12:0, a component of $E$. coli lipid A) was a potent NF- $\kappa B$ activator. The activation of NF- $\mathrm{KB}$ and COX-2 expression 
was attenuated by DHA, probably in the mechanisms of TLR4/NF-אB pathway blockage at the receptor level [11]. This stimulatory effect is not limited to immune cells. In adipocytes and endothelial cells saturated fatty acid (C18:0, palmitic acid) stimulated IKK and induced IL-6 and TNF- $\alpha$ expression also in a TLR4-dependent pathway $[91,92]$. The divergent TLR response to saturated and unsaturated fatty acids suggests some clinical implications of immunonutrition. Parenteral nutrition with fish oil increased free EPA and DHA levels and modulated cytokine response in patients with sepsis [85]. An experimental study revealed that diets enriched with fish oil/DHA might reduce inflammation after tissue damage [93]. Resolvin D1 and protectin D1, DHA-derived lipid mediators, are involved in these mechanisms. In a model of peritonitis in mice, intraperitoneal administration of protectin D1 preceding zymosan A reduced the number of neutrophils and the levels of pro-inflammatory cytokines and chemokines [94]. This means that the administration of n-3 PUFAs modulates the profile of lipid mediators not only by their impact on TLR-dependent signaling. Moreover, leukotrienes, thromboxane, and prostaglandins formed from EPA are considered to have less of a pro-inflammatory impact on the immune response [95]. We believe that parenteral n-3 PUFA administration during a hyperinflammatory reaction may have positive effects on the outcomes of critically ill patients.

\section{Probiotics}

Recently there has been evidence that TLRs may mediate immunomodulatory activity of probiotics via ligation with certain probiotic antigens and/or nucleic acids $[96,97]$. TLRs' interactions with bacterial ligands support intestinal barrier function and communication to immune cells (e.g. DCs) that play important roles in regulating intestinal homeostasis in the healthy intestine and in the dysregulated response seen in the inflammatory bowel diseases [98, 99]. In experimental colitis (hapten-induced colitis in BALB/c mice, and the IL-10 knockout mice model) the DNA of bacterial origin that binds to TLR9 has been shown to reduce inflammation [100]. The immunomodulatory function of probiotic bacterial DNA has also been demonstrated in a study of peripheral blood mononuclear cells taken from healthy donors where Bifidobacterium genomic DNA caused the induction of secretion of the antiinflammatory IL-10 [101]. In addition, probiotics have been shown to reduce NF-KB activation in intestinal inflammation [102]. A possible mechanism by which probiotics interfere with the NF- $\kappa$ B pathway is based on the fact that a mixture of probiotic bacteria elicits immunosuppressive activity by stabilizing $\mid \kappa B$ levels and inhibit- ing both NF- $\kappa B$ activation and IL-8 secretion [103]. These

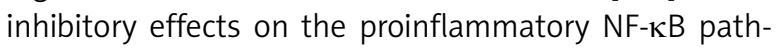
way may be an important mechanism used by probiotics to regulate intestinal inflammation and response to infection. There are insufficient data to recommend the use of probiotics in critically ill patients during enteral nutrition. In the Besselink study, there was a significantly higher need for surgical intervention and frequency of organ failures and bowel ischemia associated with the use of pre/probiotics in acute pancreatitis [104]. It was noted that their use after multiple trauma might be associated with a reduction in diarrhea in critically ill patients [105]. There is also emerging evidence for the use of probiotics in treating gastrointestinal infections, to prevent postoperative bacterial translocation, irritable bowel syndrome, in ulcerative colitis and Crohn's disease [106].

In conclusion, the above-presented results show that improving outcomes in the group of patients with severe infections requires more attention to be paid to explaining the molecular mechanisms regulating the innate antibacterial response. One of the preconditions necessary to achieve progress in treating the most severely ill patients is to find out more about the impact of nutrition, severe infections and immunonutrition on the expression of selected signaling pathway proteins of innate antibacterial response cells. Attempts to modulate the innate antibacterial immune response by administering immunonutrition are promising and indicate that in the future it may be a valuable way of assisting the basic therapy by blocking selected signaling pathways aimed at reducing the life-threatening effects of massive infection, including the increased inflammatory response.

\section{Acknowledgments}

This work was supported by Project No. 2 3068B P01 funded by the Ministry of Science and Higher Education in Poland.

\section{References}

1. Marik PE, Zaloga GP. Immunonutrition in critically ill patients: a systemic review and analysis of the litetarure. Intensive Care Med 2008; 34: 1980-90.

2. Zheng Y, Li F, Qi B, et al. Application of perioperative immunonutrition for gastrointestinal surgery: a meta-analysis of randomized controlled trials. Asi Pac J Clin Nutr 2007; 16 (Suppl 1): 253-7.

3. Petrov MS, Atduev VA, Zagainov VE. Advanced enteral therapy in acute pancreatitis: Is there a room for immunonutrition? A meta-analysis. Int J Surg 2007; 6: 119-24.

4. McClave SA, Chang WK, Dhaliwal R, et al. Nutrition support in acute pancreatitis: a systematic review of literature. JPEN J Parenter Enteral Nutr 2006; 30: 143-56. 
5. Novak F, Heyland DK, Avenell A, et al. Glutamine supplementation in serious illness: a systematic review of the evidence. Crit Care Med 2002; 30: 2022-9.

6. Heyland DK, Dhaliwal R, Day AG, et al. Reducing deaths due to oxidative stress (The REDOXS study): rationale and design for a randomized trial of glutamine and antioxidant supplementation in critically-ill patients. Proc Nutr Soc 2006; 65: 250-63.

7. Mayer K, Schaefer MB, Seeger W. Fish oil in critically ill: from experimental to clinical data. Curr Opin Clin Nutr Metab Care 2006; 9: 140-8.

8. Mayer K, Seeger W. Fish oil in critical illness. Curr Opin Clin Nutr Metab Crit Care 2008; 11: 121-7.

9. Peterik A, Milbrandt EB, Darby JM. Immunonutrition in critical illness: still fishing for the truth. Crit Care 2009; 13: 305-9.

10. Riedemann NC, Guo RF, Ward PA. Novel strategies for the treatment of sepsis. Nat Med 2003; 9: 517-24.

11. Lee JY, Sohn KH, Rhee SH, et al. Saturated fatty acids, but not unsaturated fatty acids, induce the expression of cyclooxygenase-2 mediated through Toll-like receptor 4. J Biol Chem 2001; 276: 16683-9.

12. Chang WK, Yang KD, Chuang $\mathrm{H}$, et al. Glutamine protects activated human $\mathrm{T}$ cells from apoptosis by up-regulating glutathione and Bcl-2 levels. Clin Immunol 2002; 104: 151-60.

13. Singer $P$, Shapiro $H$, Theilla $M$, et al. Anti-inflammatory properties of omega-3 fatty acids in critical illness: novel mechanisms and integrative perspective. Intensive Care Med 2008; 34: 1580-92.

14. Kessel A, Toubi E, Pavlotzky E, et al. Treatment with glutamine is associated with downregulation of Toll-like receptor-4 and myeloid differentiation factor 88 expression and decrease in intestinal mucosal injury caused by lipopolysaccharide endotoxaemia in a rat. Clin Exp Immunol 2008; 151: 341-7.

15. Cohen J. The immunopathogenesis of sepsis. Nature 2002; 420: 885-91.

16. Akira S, Uematsu S, Takeuchi O. Pathogen recognition and innate immunity. Cell 2006; 124: 783-801.

17. Kaisho T, Akira S. Toll-like receptor function and signaling J Allergy Clin Immunol 2006; 117: 979-87.

18. Akira S, Takeda K. Toll-like receptors signaling. Nat Rev Immunol 2004; 4: 499-511

19. Kawai T, Akira S. TLR signaling. Cell Death Differ 2006; 13 816-25.

20. Takeda K, Akira S. Toll-like receptors in innate immunity. Int Immunol 2005; 17: 1-14.

21. Biswas SK, Tergaonkar V. Myleoid differentiation factor 88independent Toll-like receptor pathway: sustaining inflammation or promoting tolerance? Int J Biochem Cell Biol 2007; 39: 1582-92.

22. Yamamoto $M$, Takeda K, Akira S. TIR domain-containing adaptors define the specificity of TLR signaling. Mol Immunol 2004; 40: 861-8.

23. Brint EK, Xu D, Liu H, et al. ST2 is an inhibitor of interleukin-1 receptor and Toll-like receptor 4 signaling and maintains endotoxin tolerance. Nat Immunol 2004; 5: 373-9.

24. Burns K, Janssens S, Brissoni B, et al. Inhibition of interleukin 1 receptor/Toll-like receptor signaling through the alternatively spliced, short form of MyD88 is due to its failure to recruit IRAK- 4. J Exp Med 2003; 197: 263-8.
25. Choi KC, Lee YS, Lim S, et al. Smad6 negatively regulates interleukin 1-receptor-Toll-like receptor signaling through direct interaction with the adaptor Pellino-1. Nat Immunol 2006; 7: 1057-65.

26. Divanovic S, Trompette A, Atabani SF, et al. Negative regulation of Toll-like receptor 4 signaling by the Toll-like receptor homolog RP105. Nat Immunol 2005; 6: 571-8.

27. Qin J, Qian Y, Yao J, et al. SIGIRR inhibits interleukin-1 receptorand Toll-like receptor 4-mediated signaling through different mechanisms. J Biol Chem 2005; 280: 25233-41.

28. Zhang G, Ghosh S. Negative regulation of Toll-like receptormediated signaling by Tollip. J Biol Chem 2002; 277: 7059-65.

29. Hoebe K, Du X, Goergel P, et al. Identification of Lps2 as a key transducer of MyD88- independent TIR signaling. Nature 2003; 424: 743-8.

30. Kawai T, Adachi O, Ogawa T, et al. Unresponsiveness of MyD88-deficient mice to endotoxin. Immunity 1999; 11: 115-22.

31. Yamamoto M, Sato S, Hemmi H, et al. Role of adaptor TRIF in the MyD88-independent Toll-like receptor signaling pathway. Science 2003; 301: 640-3.

32. Yamamoto $M$, Sato $S$, Mori $K$, et al. Cutting edge: a novel Toll/IL-1 receptor domain-containing adapter that preferentially activates the IFN-beta promoter in the Toll-like receptor signaling. J Immunol 2002; 169: 6668-72.

33. Takeuchi O, Takeda K, Hoshino K, et al. Cellular responses to bacterial cell wall components are mediated through MyD88dependent signaling cascades. Int Immunol 2000; 12: 113-7.

34. Weighardt $\mathrm{H}$, Kaiser-Moore $\mathrm{S}$, Vabulas RM, et al. Cutting edge: myeloid differentiation factor 88 deficiency improves resistance against sepsis caused by polymicrobial infection. J Immunol 2002; 169: 2823-7.

35. Adib-Conquy $M$, Adrie $C$, Fitting $C$, et al. Up regulation of MyD88 and SIGIRR, molecules inhibiting Toll Like receptor signaling in monocytes from septic patients. Crit Care Med 2006; 34: 2377-85.

36. Adib-Conquy $\mathrm{M}$, Moine $\mathrm{P}$, Asehnoune $\mathrm{K}$, et al. Toll Like receptor mediated tumor necrosis factorand interleukin 10 production differ during systemic inflammation. Am J Respir Crit Care Med 2003; 168: 158-64.

37. Brandl K, Gluck T, Huber C, et al. TLR4 surface display is increased in septic patients. Eur J Med Res 2005; 10: 319-24.

38. Salgado AR, Comesańa VR, Bárcena JP, et al. La glutamina como compuesto modulador de la respuesta inflamatoria en pacientes críticos con nutrición parenteral: efecto sobre la expresión y funcionalidad de los receptores Toll-Like. Nutr Hosp 2006; 21 (Suppl 1): 65

39. Feterowski C, Emmanuildis K, Miethke T, et al. Effects of functional Toll-like receptor-4 mutations in the immune response to human and experimental sepsis. Immunology 2003; 109: 426-31.

40. Qureshi ST, Medzhitov R. Toll-like receptors and their role in experimental models of microbial infection. Genes Immun 2003; 4: 87-94.

41. Akira S. Toll-like receptor signalling. J Biol Chem 2003; 278: 38105-8.

42. Blander JM, Medzhitov R. Regulation of phagosome maturation by signals from Toll-like receptors. Science 2004; 304: 1014-8. 
43. Medzhitov R, Janeway C. Innate immune recognition: mechanism and pathways. Immunol Rev 2000; 173: 89-97.

44. Baumgarten $\mathrm{G}$, Knuefermann $\mathrm{P}$, Wrigge $\mathrm{H}$, et al. Role of Tolllike receptor 4 for the pathogenesis of acute lung injury in Gram-negative sepsis. Eur J Anaesthesiol 2006; 23: 1041-8.

45. Ren Y, Xie Y, Jiang G, et al. Apoptotic cells protect mice against lipopolisaccharide-induced shock. J Immunol 2008; 180: 4978-85.

46. Goshima M, Kotani J, Lowry SF, et al. LPS-induced decrease of neutrophil apoptosis is regulated through TLR2, not through TLR4. J Am Coll Surg 2004; 199: 38.

47. Neu J, Auestad N, DeMarco VG. Glutamine metabolism in the fetus and critically ill low birth weight neonate. Adv Pediatr 2002; 49: 203-26.

48. Foitzik T. Pancreatitis and nutrition. Significance of the gastrointestinal tract and nutrition for septic complications. Zentralbl Chir 2001; 4: 126-9.

49. Houdijk AP, Rijnsburger ER, Jansen J, et al. Randomised trial of glutamine-enriched enteral nutrition on infectious morbidity in patients with multiple trauma. Lancet 1998; 352: 772-6.

50. Bruke DJ, Alverdy JC, Aoys E, et al. Glutamine-supplemented total parenteral nutrition improves gut immune function. Arch Surg 1989; 124: 1396-9.

51. Furukawa S, Saito $H$, Inoue $T$, et al. Supplemental glutamine augments phagocytosis and reactive oxygen intermediate production by neutrophils and monocytes from postoperative patients in vitro. Nutrition 2000; 16: 323-9.

52. Oudemans-van Straaten HM, Bosman RJ, Treskes M, et al. Plasma glutamine depletion and patient outcome in acute ICU admissions. Intensive Care Med 2001; 27: 84-90.

53. Liboni KC, Li N, Scumpia PO, et al. Glutamine modulates LPS-Induced IL-8 production through IkappaB/NF-kappaB in human fetal and adult intestinal epithelium. J Nutr 2005; 135 245-51.

54. Murphy C, Newsholme P. Macrophages-mediated lysis of betacell line, tumour necrosis factor-alpha release from bacillus Calmette-Guerin (BCG)-activated murine macrophages and interleukin-8 release from human monocytes are dependent on extracellular glutamine concentration and glutamine metabolism. Clin Sci 1999; 96: 89-97.

55. Wischmeyer PE, Kahana MD, Wolfson R, et al. Glutamine induces heat shock protein and protects against endotoxin shock in the rat. J Appl Physiol 2001; 90: 2403-10.

56. Wischmeyer PE, Riehm J, Singleton KD, et al. Glutamine attenuates tumor necrosis factor-alpha release and enhances heat shock protein 72 in human peripheral blood mononuclear cells. Nutrition 2003; 19: 1-6.

57. Cario E, Rosenberg IM, Brandwein SL, et al. Lipopolysaccharide activates distinct signaling pathways in intestinal epithelia cell lines expressing Toll-like receptors. J Immunol 2000; 164: 966-72.

58. Abreu MT, Vora P, Faure E, et al. Decreased expression of Tolllike receptor-4 and MD-2 correlates with intestinal epithelial cell protection against dysregulated proinflammatory gene expression in response to bacterial lipopolysaccharide. J Immuno 2001; 167: 1609-19.

59. Pérez-Bárcena J, Regueiro V, Marsé $P$, et al. Glutamine as a modulator of the immune system of critical care patients: Effect on Toll-like receptor expression. A preliminary study. Nutrition 2008; 24: 522-7.
60. Pérez-Bárcena J, Crespí C, Regueiro V, et al. Lack of effect of glutamine adnimistration to boost the innate immune system response in trauma patients in the intensive race unit. Crit Care 2010; 14: R233.

61. Aosasa S, Mochizuki H, Yamamoto T, et al. A clinical study of the effectiveness of oral glutamine supplementation during total parenteral nutrition: influence on mesenteric mononuclear cells. JPEN 1999; 23: S41-4.

62. O'Riordain MG, De Beaux A, Fearon KC. Effect of glutamine on immune function in the surgical patient. Nutrition 1996; 12: S82-4.

63. Ogle CK, Ogle JD, Mao JX, et al. Effect of glutamine on phagocytosis and bacterial killing by normal and pediatric burn patient neutrophils. JPEN 1994; 18: 128-33.

64. Lecleire S, Hassan A, Marion-Letellier R, et al. Combined glutamine and arginine decrease proinflammatory cytokine production by biopsies from Crohn's patients in association with changes in nuclear factor-kappa B and p38 mitogen-activated protein kinase pathways. J Nutr 2008; 138: 2481-6.

65. Braga M, Vignali A, Gianotti L, et al. Immune and nutritional effects of early enteral nutrition after major abdominal operations. Eur J Surg 1996; 162: 105-12.

66. Kudsk KA, Minard G, Croce MA, et al. A randomized trial of isonitrogenous enteral diets after severe trauma. An immuneenhancing diet reduces septic complications. Ann Surg 1996; 224: 531-43.

67. Senkal M, Mumme A, Eickhoff U, et al. Early postoperative enteral immunonutrition: clinical outcome and cost-comparison analysis in surgical patients. Crit Care Med 1997; 25 : 1489-96.

68. Barton RG, Wells CL, Carlson A, et al. Dietary omega-3 fatty acids decrease mortality and kupffer cell prostaglandin E2 production in a rat model of chronic sepsis. J Trauma 1991; 31: 768-74.

69. Grimminger F, Wahn H, Mayer K, et al. Impact of arachidonic versus eicosapentaenoic acid on exotoxin-induces lung vascular leakage. Am J Respir Crit Care Med 1997; 155: 513-9.

70. Johnson JA, Griswold JA, Muakkassa FF. Essential fatty acids influence survival in sepsis. J Trauma 1993; 35: 128-31.

71. Chakrabati R, Hubbard NE, Lin D, et al. Alteration of plateletactivating factor-induced signal transduction in macrophages by $n-3$ fatty acids. Cell Immunol 1997; 175: 76-84.

72. Diep QN, Intengan HD, Schiffrin EL. Endothelin-1 attenuates n-3 fatty acid-induced apoptosis by inhibition of caspase 3 . Hypertension 2000; 35: 278-91.

73. Calder PC. N-3 polyunsaturated fatty acids, inflammation, and inflammatory diseases. Am J Clin Nutr 2006; 83 (6 Suppl): 1505S-19S.

74. Li H, Ruan XZ, Powis SH, et al. EPA and DHA reduce LPS-induced inflammation responses in HK-2 cells: evidence for a PPARgamma-dependent mechanism. Kidney Int 2005; 67: 867-74.

75. Mishra A, Chaudhary A, Sethi S. Oxidized omega- 3 fatty acids inhibit NFkappaB activation via a PPARalpha-dependent pathway. Arterioscler Thromb Vasc Biol 2004; 24: 1621-7.

76. Moon DO, Kim KC, Jin CY, et al. Inhibitory effects of eicosapentaenoic acid on lipopolysaccharide-induced activation in BV2 microglia. Int Immunopharmacol 2007; 7: 222-9.

77. Novak TE, Babcock TA, Jho DH, et al. NF-kappa B inhibition by omega-3 fatty acids modulates LPS-stimulated macrophage 
TNF-alpha transcription. Am J Physiol Lung Cell Mol Physiol 2003; 284: L84-9.

78. Weldon SM, Mullen AC, Loscher CE, et al. Docosahexaenoic acid induces an anti-inflammatory profile in lipopolysaccharide-stimulated human THP-1 macrophages more effectively than eicosapentaenoic acid. J Nutr Biochem 2007; 18: 250-8.

79. Wendel M, Paul R, Heller AR. Lipoproteins in inflammation and sepsis. II. Clinical aspects. Intensive Care Med 2007; 33: 25-35.

80. Zhao Y, Joshi-Barve S, Barve S, et al. Eicosapentaenoic acid prevents LPS-induced TNF-alpha expression by preventing NF-kappaB activation. J Am Coll Nutr 2004; 23: 71-8.

81. Tsukumo DM, Carvalho-Filho MA, Calvalheyra JB, et al. Loss-offunction mutation in Toll-like receptor 4 prevents diet-induced obesity and insulin resistance. Diabetes 2007; 56: 1986-98.

82. Pontes-Arruda A, Aragao AM, Albuquerque JD. Effects of enteral feeding with Eicosapentaenoic acid, gamma-linolenic acid, and antioxidants in mechanically ventiled patients with severe sepsis and septic shock. Crit Care Med 2006; 34: 2325-33.

83. Singer $P$, Theilla $M$, Fisher $H$, et al. Benefit of an enteral diet enriched with eicosapentaenoic acid and gamma-linolenic acid in ventilated patients with acute lung injury. Crit Care Med 2006; 34: 1033-8.

84. Mayer K, Fegbeutel C, Hattar K, et al. Omega-3 vs. omega-6 lipid emulsions exert differential influence on neutrophils in septic shock patients: impact on plasma fatty acids and lipid mediator generation. Intensive Care Med 2003; 29: 1472-81.

85. Mayer K, Gokorsch S, Fegbeutel C, et al. Parenteral nutrition with fish oil modulates cytokine response in patients with sepsis. Am J Respir Crit Care Med 2003; 167: 1321-8.

86. Tiesset H, Pierre M, Desseyn JL, et al. Dietary (n-3) polyunsaturated fatty acids affect the kinetics of pro- and anti-inflammatory responses in mice with Pseudomonas aeruginosa lung infection. J Nutr 2009; 139: 82-9.

87. Gabler NK, Spencer JD, Webel DM, et al. n-3 PUFA attenuate lipopolysaccharide-induced down-regulation of toll-like receptor 4 expression in porcine adipose tissue but does not alter the expression of other immune modulators. J Nutr Biochem 2008; 19: 8-15.

88. Petursdottir DH, Hardardottir I. Dietary fish oil increases the number of splenic macrophages secreting TNF-alpha and IL-10 but decreases the secretion of these cytokines by splenic T cells from mice. J Nutr 2007; 137: 665-70.

89. Baeza I, de Castro NM, Arranz L, et al. Expression of Toll-like receptors on peritoneal macrophages and dendritic cells from old mice treated with soyabean isoflavones and green tea. Proc Nutr Soc 2008; 67(OCE): E27.

90. Lee JY, Hwang DH. The modulation of inflammatory gene expression by lipids: mediation through Toll-like receptors. Mol Cells 2006; 21: 174-85.

91. Shi H, Kokoeva MV, Inouye K, et al. TLR4 links innate immunity and fatty acid-induced insulin resistance. J Clin Invest 2006; 116: 3015-25.

92. Kim F, Pham M, Luttrell I, et al. Toll-like receptor-4 mediated vascular inflammation and insulin resistance in diet-induced obesity. Circ Res 2007; 100: 1589-96.

93. Gonzalez-Periz A, Planaguma A, Gronert K, et al. Docosahexaenoic acid (DHA) blunts liver injury by conversion to protective lipid mediators: protectin D1 and 17S-dydroxy-DHA. FASEB J 2006; 20: 2537-9.
94. Bannenberg GL, Chiang N, Ariel A, et al. Molecular circuitis of resolution: formation and actions of resolvins and protectins. J Immunol 2005; 174: 4345-55.

95. Calder PC. $n-3$ polyunsaturated fatty acids and inflammation: from molecular biology to the clinic. Lipids 2003; 38: 343-52.

96. Christensen HR, Frokiaer H, Pestka JJ. Lactobacilli differentially modulate expression of cytokines and maturation surface markers in murine dendritic cells. J Immunol 2002; 168: 171-8.

97. Mills KH, McGuirk P. Antigen-specific regulatory T cells-their induction and role in infection. Semin Immunol 2004; 16: 107-17.

98. Rakoff-Nahoum S, Paglino J, Eslami-Varzaneh F, et al. Recognition of commensal microflora by toll-like receptors is required for intestinal homeostasis. Cell 2004; 118: 229-41.

99. Stagg AJ, Hart AL, Knight SC, et al. Microbial-gut interactions in health and disease. Interations between dendritic cells and bacteria in the regulation of intestinal immunity. Best Pract Res Clin Gastroenterol 2004; 18: 255-70.

100. Rachmilewitz D, Karmeli F, Takabayashi K, et al. Immunostimulatory DNA ameliorates experimental and spontaneous murine colitis. Gastroenterology 2002; 122: 1428-41.

101. Lammers KM, Brigidi P, Vitali B, et al. Immunomodulatory effects of probiotic bacteria DNA: IL-10 and IL-10 response in human peripheral blood mononuclear cells. FEMS Immunol Med Microbiol 2003; 38: 165-72.

102. Petrof EO, Kojima K, Ropeleski MJ, et al. Probiotics inhibit nuclear factor-kappaB and induce heat shock proteins in colonic epithelial cells through proteasome inhibition. Gastroenterology 2004; 127: 1474-87.

103. Jijon H, Backer J, Diaz H, et al. DNA from probiotic bacteria modulates murine and human epithelial and immune function. Gastroenterology 2004; 126: 1358-73.

104. Besselink MG, van Santvoort HC, Buskens E, et al. Probiotic prophylaxis in predicted severe acute pancreatitis: a randomised, double-blind, placebo-controlled trial. Lancet 2008; 371: 651-9.

105. Kotzampassi K, Giamarellos-Bourboulis EJ, Voudouris A, et al. Benefits of a symbiotic formula (Synbiotic 2000Forte) in critically ill trauma patients: early results of a randomized controlled trial. World I Surg 2006; 30: 1848-55.

106. Harish K, Varghese T. Probiotics in humans - evidence based review. Calicut Med J 2006; 4: e3. 